\title{
Evaluation of Antioxidant and Antimicrobial Activity in Relation to Total Phenolic Content of Green Algae from Black Sea
}

\author{
RODICA SIRBU ${ }^{1}$, GABRIELA STANCIU²*, ANETA TOMESCUㄴ, ANA MARIA IONESCU³, EMIN CADAR ${ }^{1}$ \\ ${ }^{1}$ Ovidius University of Constanta, Faculty of Pharmacy, 124 Mamaia Blvd., 900527, Constanta, Romania \\ ${ }^{2}$ Ovidius University of Constanta, Department of Chemistry and Chemical Engineering, 124 Mamaia Blvd., 900527, Constanta, \\ Romania \\ ${ }^{3}$ Ovidius University of Constanta, Faculty of Medicine, 900527, 124 Mamaia Blvd., Constanta, Romania
}

\begin{abstract}
Worldwide, marine algae are known to produce a wide variety of bioactive secondary metabolites and several compounds have been derived from them for the prospective development of novel drugs by the pharmaceutical industry. In this context, Ulva lactuca, Enteromorpha intestinales, and Cladophora vagabunda, isolated from Black Sea coastal waters of Romania, were evaluated for their potential for bioactivity. Extracts of the algae selected for the study were prepared using ethanol. The study presents original results concerning the total phenolic content (TPC), determined by the spectrometric method (Folin-Ciocalteu method) and the individual phenols from each species of seaweed studied were identified by HPLC-DAD techniques. Total antioxidant activity (ACL) was studied by photochemiluminescence method, and antibacterial activity was studied on two strains of bacteria, Escherichia coli ATCC 10536 - gram-negative and Staphylococcus aureus ATCC 6538P - gram-positive. Results indicated that the highest total phenolic content was obtained for Cladophora vagabunda (325.8 mg/100 g f.w.), followed by Ulva lactuca $(285.5 \mathrm{mg} / 100 \mathrm{~g}$ f.w.) and the lowest rate was registered by Enteromorpha intestinalis $(268.8 \mathrm{mg} / 100 \mathrm{~g}$ f.w.). Through HPLC-DAD techniques, 6 individual phenolic compounds were identified in all analyzed seaweeds. In addition, two other phenolic compounds were identified in lower concentrations in Ulva lactuca, but only one phenolic compound in Enteromorpha intestinalis. The results of this study show that there is a strong correlation between antioxidant activity (ACL), antibacterial activity and total phenolic content (TPC). Antioxidant activity shows the same order as total phenolic content (TPC): Cladophora vagabunda (64.15 $\mathrm{nmol} / \mathrm{g} \mathrm{sample)}$ followed by Ulva lactuca (22.8 nmol/g sample) and Enteromorpha intestinalis (10.4 nmol/g sample). The antibacterial activity recorded in all green seaweeds shows that the inhibition sites are higher on Escherichia coli compared to Staphylococcus aureus.
\end{abstract}

Keywords: green seaweeds, antioxidant activity, antibacterial activity, total phenolic content, HPLC-DAD

The effects of lightand the presence of oxygen and active free radicals $\left(\mathrm{O}_{2}, \mathrm{OH} \bullet, \mathrm{LOO} \bullet\right)$ on living systems has become a frequently researched topic [1]. Oxidative degradation of lipids from raw or processed food products is not responsible only for the loss of nutritional value, but it also contributes to carcinogenesis, atherosclerosis and the ageing process in humans [2]. Phenols are extremely efficient antioxidants for polyunsaturated fatty acids; in fact, they can easily transfer a hydrogen atom to the peroxyl lipid radical (LOO) thus forming the aryloxy radical (ArO), which cannot act as chain carrier. This couples itself with another radical, thus stopping the chain process [3]. Amongst marine organisms, algae represent one of the richest sources of antioxidants [4]. Phenolic compounds are present in all plants [5-7]. They can be found in significant quantities in algae, alongside other important active biologic compounds, such as polysaccharides, fatty acids, proteins, terpenes, and so on, which suggest antitumor, antibacterial, antiviral and antioxidant activity $[8,9]$. Marine algae are distributed globally in seas and oceans and can be found attached to rocks or other hard substrates from coastal regions, with an $0.01 \%$ availability of photosynthetic light [10]. These can be found in every climate area, from warm tropical waters to polar, freezing regions [11]. Green algae can be found worldwide, growing in intertidal zones, attached to a hard substrate or free [12]. These are considered opportunistic algae and they proliferate in eutrophic coastal waters [13]. There are numerous studies regarding green algae $[14,15]$. Thus, phenols and active biologic compounds have been found in several green algae species which can be observed in various seas and oceans [16]. Marine algae have been studied in the past years as a potential source of bioactive compounds, due to the fact that they have the ability of producing a series of secondary metabolites with a variety of interesting biological effects, such as antimicrobial, antiviral and antioxidant activity $[17,18]$. There has been a particular interest in researching new antimicrobial substances originating from green marine algae from various seas and oceans [19-21]. Algae contain a high number of antibacterial compounds, such as fatty acids [22], phenols [23], steroids [24, 25] and halogenated compounds [26, 27]. In the past years, algae extracts have been widely used in the prevention and treatment of viral and bacterial disease in aquatic animals [28]. Algae extracts have shown a powerful antibacterial activity against aquatic pathogenic bacteria [29]. From the green algae, Ulva lactuca has been studied by numerous researchers and ithas become a model for morphogenetic studies [30]. Studies regarding green algae composition were also performed by other researchers who have taken into account the seasonal changes in compositions for U/va lactuca [31]. Other studies have determined the chemical composition of ulvan [32,33] and have isolated extracts with antioxidant and antibacterial activity [34-36]. The Black Sea, like other seas and oceans, offers a rich algae mass which can be harvested, thus representing an important resource for the medical and pharmaceutical fields [37]. Until now, studies regarding the characterization of marine algae, which have been used in various purposes, have been performed [38]. Regarding Black Sea algae, marine habitats in which algae develop have been studied, 
especially in the Romanian shore area [39]. However, the antioxidant and antimicrobial activity of the seaweed remains unexplored. The main objective of this paper is to evaluate the total phenol content and its correlation with antioxidant and antimicrobial activity of Clorophyta green algae. The following species have been selected: UIva Lactuca (Linnaeus, 1753) [40] and Enteromorpha intestinales (Linnaeus-Nees, 1820) from the Ulvophyceae class, Ulvales order, Ulvaceae family and Cladophora vagabunda (Linnaeus-van den Hoek, 1963) [41], from the Chlorophyceae class, Cladophorales order, Cladophoraceae family. Phenolic content in alcoholic extracts from algae harvested from six different regions of the Romanian shore was determined, and the antioxidant (ACL) and antimicrobial activity of the algae was evaluated. The total phenolic content was determined through the Folin-Ciocalteu methods. Phenolic compounds from green algae extracts were determined through HPLCDAD techniques. Antioxidant capacity (ACL) was evaluated through the chemiluminescence method, using trolox as the standard substance. Green algae antibacterial activity was evaluated on two strains of bacteria: gram negative Escherichia coli and gram positive Staphylococcus aureus.

\section{Experimental part}

Plant materials

The samples of green seaweed were collected during J uly-Octomber 2017, when algae reach maturity in different harvesting sites. Samples were harvested from 6 areas, and named as: S1 through S6: S1- Mamaia North, S2 Constanta Casino, S3 -Constanta harbor, S4 -Eforie South, S5 -Costinesti, S6- Mangalia. Each collected sample was thoroughly washed with seawater to remove all the extraneous matter such as epiphytes, sand particles, pebbles and shells. In the laboratory the sample was cleaned with fresh water and distilled water, then dried and powdered using mixture grinder. The powdered seaweeds were passed through a $0.5 \mathrm{~mm}$ sieve in order to obtain a uniform powder which was stored in the freezer until extraction.

\section{Chemicals}

All used reagents were of analytical reagent grade. Gallic acid was purchased from Fluka and Folin - Ciocalteu reagent from Merck. Gallic acid (standard phenol compound) $1 \times 10^{-2} \mathrm{~mol} \mathrm{~L}^{-1}$ solution was prepared by dissolving $376 \mathrm{mg}$ of gallic acid in $100 \mathrm{~mL}$ of ethanol. Folin - Ciocalteu reagent was diluted with distilled water 1:10 (v:v). The gram positive and gram negative bacteria strains were grown on culture media.

\section{Apparatus}

Spectrometric measurements were carried out using a UV-Vis Cintra 10e scanning spectrophotometer. The identification and quantitative determination of phenolic compounds were performed using HPLC system (Agilent 1200) with quaternary pump, DAD, auto sampler. The antioxidant capacity of lipid soluble substances determination was performed with a Photochem instrument with $\mathrm{ACL}$ kit (Analytic J ena $\Delta \mathrm{G}$ ).

\section{Preparation of algal extract}

Ethanol was used as an extraction solvent. For the preparation of the ethanol extract, $5 \mathrm{~g}$ of powdered seaweed was extracted overnight with $50 \mathrm{~mL}$ of $70 \%$ ethanol (v:v) at room temperature and centrifuged at 2800 rpm for $10 \mathrm{~min}$. The supernatant was collected in a separate bottle and the residue was re-extracted three times under the same conditions as mentioned above. The combined filtrate was evaporated in a rotary evaporator (BUCHI) below $40{ }^{\circ} \mathrm{C}$. The extract obtained after evaporation of the organic solvent was weighed for calculation of extraction yield and was used as a natural antioxidant.

\section{Determination of total phenolic content (TPC)}

Total phenolic contents in extracts were determined according to the Folin - Ciocalteu method $[42,43]$ using a UV spectrophotometer (Cintra Xe) according to a colorimetric reduction of a phosphowolframate phosphomolibdate complex to blue products in sodium carbonate media. The absorbance relative to a gallic acid standard curve was measured and results are expressed as gallic acid equivalents (mgGAE/L). All samples were performed in triplicate and the mean value was reported.

\section{Calibration curve}

The calibration curve (fig. 1) was graphically represented by mixing $1 \mathrm{~mL}$ aliquots of 50,100, 150,200,250,300, 350, 400 and $450 \mathrm{mg} / \mathrm{L}$ gallic acid solutions with $5.0 \mathrm{~mL}$ of FolinCiocalteu reagent $(1: 10)$ and $4.0 \mathrm{~mL}$ of sodium carbonate solution ( $75 \mathrm{~g} / \mathrm{L}$ ). Absorbance was measured after $30 \mathrm{~min}$ at $765 \mathrm{~nm}$. In order to determine total phenolic content from ethanol extracts, $1 \mathrm{~mL}$ of sample was mixed with the same reagents as the ones used for the calibration curve.

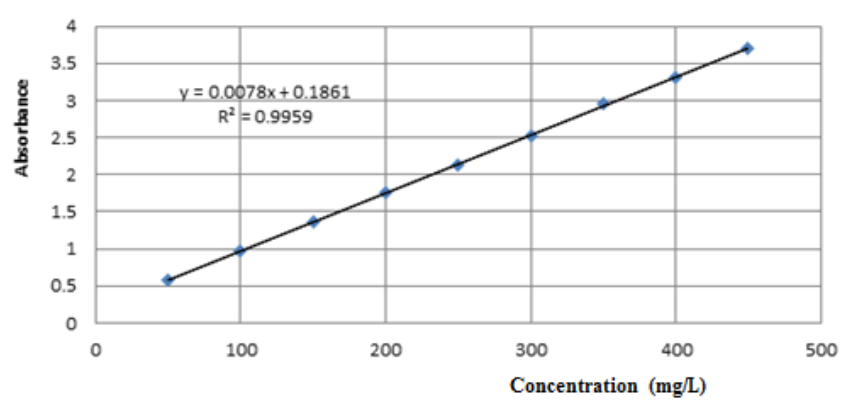

Fig.1. Calibration curve of gallic acid standard

The amount of total phenol contents was calculated as Gallic acid equivalents in $\mathrm{mg} / 100 \mathrm{~g}$ of dried seaweed ( $\mathrm{mg}$ $\mathrm{GAE} / 100 \mathrm{~g}$ f.w.).

\section{Identification of phenolic acids by HPLC}

Identification of phenolic acid was performed through HPLC-DAD method. The extract was passed through a 0.45 $\mu \mathrm{m}$ filter (Millipore) before being injected into the HPLC. Reverse phase HPLC was performed with an Agilent 1100 series HPLC (Agilent Technologies), equipped with a DAD detector (Agilent G13158). The column used was a ZORBAX Eclipse XDB C8 analytical column ( $150 \times 4.6 \mathrm{~mm})$ with a 5 m packing material. The elution was performed with an isocratic mixture of methanol and $10 \mathrm{mM}$ ammonium acetate buffer, $p H 5.4(12: 88 \mathrm{v} / \mathrm{v})$ at a flow of $1 \mathrm{~mL} / \mathrm{min}$. Detection was done using a diode array detector (DAD) with reference wavelength of $280 \mathrm{~nm}$. Retention times and peak areas were monitored and computed automatically by Chem 32 integrator (Agilent). The standard reference substances chosen were gallic acid, protocatechuic acid, gentisic acid, p-hydroxybenzoic acid, vanillic acid, caffeic acid, salicylic acid, benzoic acid, ferulic acid, elagic acid and p-coumaric acid, for which a 0.05 $\mathrm{mg} / \mathrm{mL}$ concentration was established. Standards were provided by Sigma Aldrich. Individual phenolic acids were identified by comparing the retention time of sample chromatographic peaks with those of authentic standards using the same HPLC operating conditions. Table 1 presents the determined retention time of standards. 
Table 1

THE RETENTION TIME OF STANDARDS

\begin{tabular}{|l|l|c|}
\hline No. & \multicolumn{1}{|c|}{ Standards } & Retention time \pm SD \\
\hline & Gallic acid & $0.990 \pm 0.025$ \\
\hline & Protocatechuic acid & $3.630 \pm 0.008$ \\
\hline & Gentisic acid & $4.272 \pm 0.009$ \\
\hline & p-Hydroxybenzoic acid & $5.933 \pm 0.006$ \\
\hline & Vanillic acid & $7.752 \pm 0.003$ \\
\hline & Caffeic acid & $8.981 \pm 0.061$ \\
\hline & Salicylic acid & $9.177 \pm 0.051$ \\
\hline & Benzoic acid & $9.468 \pm 0.098$ \\
\hline & Ferulic acid & $10.488 \pm 0.009$ \\
\hline & Elagic acid & $15.630 \pm 0.031$ \\
\hline
\end{tabular}

\section{Statistical analysis}

All experiments were conducted in triplicate and ANOVA (using SPSS 11.5 statistics) software was used to compare the mean values of each treatment. Significant differences between the means values of parameters were determined by using the Duncan test $(P<0.05)$.

\section{Determination of total antioxidant activitiy ( $A C L$ )}

The ACL assay was performed using Photochem instrument (Analytic Jena) against the superoxide anion radicals from luminol as photosensitizer, upon the UV light [44]. In order to determine total antioxidant capacity (ACL) of biological samples, the well dried algae were triturated to a fine powder, after which a cold extract was obtained from each alga species, using $20 \mathrm{mg}$ of dried vegetal product dissolved in $1 \mathrm{~mL}$ ethylic alcohol p.a. [45]. Extraction was performed for $24 \mathrm{~h}$ at room temperature in yellow glass sealed bottles. Mixtures were stirred regularly and extraction separation was performed through decantation, without filtration. Antioxidant capacity was determined using the standardized ACL method (antioxidant capacity of lipid soluble substances, Analytik Jena 10) in comparison to the standard substance trolox (brand name Hoffman-La Roche-6-hydroxy-2, 5, 7, 8tetramethylchromen-2-carboxylic). For the calibration curve, an Analytic J ena standard reagent kitts was used: R1 (dilution solvent), R2 (buffer reagent), R3 (photosensitive reagent), R4 (reagent dimension).

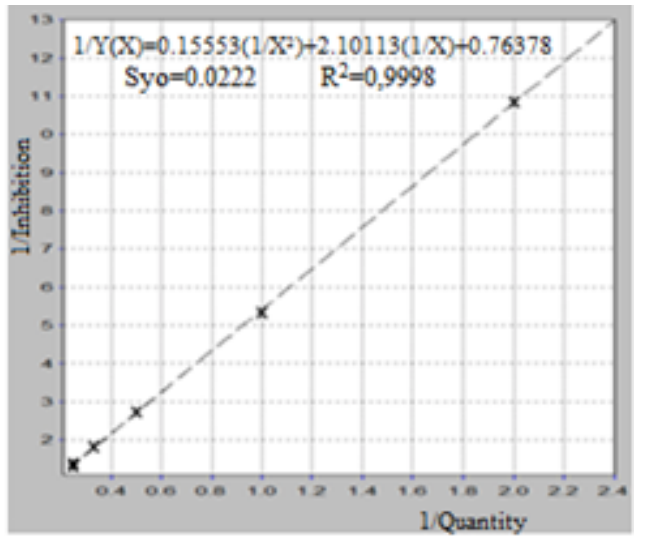

Fig. 2. Calibration curve for trolox in the calculation of trolox equivalents for $\mathrm{ACL}$ measurements (generated by PCLsoft)
The calibration curve was designed through the measurement of a series of standard solutions containing $0.5,1.0,2.0,3.0$ and $4.0 \mathrm{nmol}$ trolox and is presented in Fig. 2. Photochemical reaction was generated by exposure to external radiation from a $\mathrm{Hg}$ lamp which yields maximum energy at $\lambda=351 \mathrm{~nm}$. Total antioxidant capacity of the sample was measured by comparison to the trolox standard, in standard equivalent units [45].

\section{Antibacterial activity}

In order to test antimicrobial activity of the green seaweed, we used several culture media. We worked on two types of bacteria: gram-positive Staphylococcus aureus ATCC 6538P and gram-negative Escherichia coli ATCC 10536. The analysis method used was the nutrient agar well diffusion method. The methodology involves the preparation of nonspecific nutrient agar plates, filled with a known concentration of bacterial medium and measuring the inhibition halos formed by the ethanol extractsolutions from green seaweed. Algae species were washed, dried and brought to a corresponding grinding degree. Dried algae were subjected to ethanol extraction $(5 \mathrm{~g}$ pow der per 100 $\mathrm{mL}$ ethanol) through continuous stirring at $37^{\circ} \mathrm{C}$, for $24 \mathrm{~h}$. The samples were subjected to centrifugation for 30 minutes and the supernatant was evaporated under vacuum. The extracts were re-dissolved in ethanol.

\section{Preparation of nutrient agar plates}

Culture media was prepared for each strain, Staphylococcus aureus and Escherichia coli (fig.3). Petri dished in which $1 \mathrm{~mL}$ reference solution (Inocculum) and $80 \mathrm{~mL}$ of nonspecific nutrient agar were added, sterilized and homogenized (fig.3). The plates were left to cool at room temperature until the agar became solid. Two plates with positive witness samples were also prepared in order to compare results.

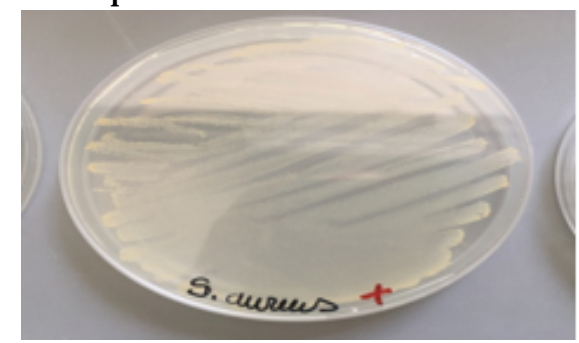

Fig.3 Culture media for Staphylococcus aureus and Escherichia coli

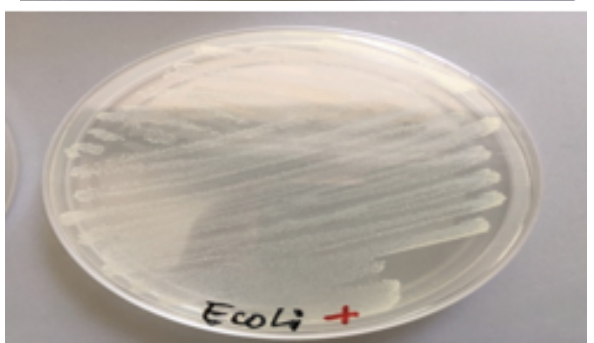

For each of the strain, a standardized reference solution with a known concentration $\left(3 \times 10^{-8} \mathrm{~g} / \mathrm{mL}\right)$ was prepared. After solidification of the agar from the Petri dishes the wells were made, using a sterilized matrix with a known diameter, corresponding to each solution volume. Thus, for a $0.25 \mathrm{~mL}$ volume, was a matrix with a diameter of 10 $\mathrm{mm}$ was used, whereas, for a $0.5 \mathrm{~mL}$ volume, we used a matrix with a diameter of $15 \mathrm{~mm}$, and for a $1 \mathrm{~mL}$ volume, the a diameter was of $17 \mathrm{~mm}$. Interpretation of the results of this antimicrobial analysis was performed through the comparison of the obtained samples with the positive witness plate for each studies pathogen culture. The diffusion radius of the green algae extract solution in the agar contaminated with the study strain was measured. 
The halo formed around the wells represents growth inhibition and the halt of pathogen spread; the radii differ according to the type of alga, as well as the concentration and the solution volume from the algae extracts.

\section{Statistical analysis}

A statistical approach was designed and the experimental data were evaluated using one-way analysis of variance (ANOVA), with $p<0.05$ as threshold for statistical significance. The statistical results confirm the hypothesis that the differences between the results are either not significant ( $p>0.05$ ). The average of multiple measurements (triplicates or more) was listed in the tables together with the standard deviations. Statistical analysis was performed using Excel software package.

\section{Results and discussions}

\section{Total phenol content (TPC)}

Three different green seaweed from the Clorophyta class were studied: Ulva lactuca, Enteromorpha intestinalesand Cladophora vagabunda. The results of total phenolic content (TPC) determined for ethanol extracts of these green algae are presented in table 2 .

The total phenolic content ranged from 268.8 to 325.8 $\mathrm{mg} / 100 \mathrm{~g}$ dried seaweed in ethanol. The lowest, but still rich, total phenolic content was obtained for Enteromorpha intestinalis ( $268.8 \mathrm{mg} / 100 \mathrm{~g}$ f.w.). The highest total phenolic content was obtained for Cladophora vagabunda (325.8 $\mathrm{mg} / 100 \mathrm{~g}$ f.w.) followed by Ulva lactuca (285.5 mg/100 g f.w.).

There are studies in literature which outline the fact that the type of solvent influences selectivity of phenol compounds [42]. The study performed by Wang et al. [23], shows that water as solvent is inferior to polar organic solvents in the extraction of polyphenolic compounds, which confirms our use of ethanol as a solvent.

\section{HPLC analysis of phenol compounds}

Table 3 presents the individual phenolic concentrations determined by HPLC -DAD expressed in $\mathrm{mg} / 100 \mathrm{~g} \mathrm{f}$. w. By correlating the total phenolic content (TPC) and individual phenols the majority phenolic content can also be expressed as percentage (table 4). It can be observed that the total phenols identified and quantified were in different percentages for the ethanol extracts from the three algae. The highest percentage of individual phenols was identified in Ulva lactuca $(79.96 \%)$, followed by Cladophora vagabunda (74.6\%), while the lowest percentage was obtained for Enteromorpha intestinalis (67.93\%). Table 3 shows that all three Clorophytele green algae contain gentisic acid; the highest quantity was identified in Cladophora vagabunda ( $155.3 \mathrm{mg} / 100 \mathrm{~g}$ f.w.), followed by Ulva lactuca (130.5 mg/100 g f.w.) and Enteromorpha intestinalis $(98.6 \mathrm{mg} / 100 \mathrm{~g}$ f.w.). If we correlate the total phenol content (TPC) identified and quantified in the analyzed seaweed with the gentisic acid content found (see Table 4), it can be observed that this acid has the highestpercentage of total existing phenols in Ulva lactuca (46.0\%), followed by $43.52 \%$ in Cladophora vagabunda and $36.68 \%$ in Enteromorpha intestinalis.

Protocatechuic acid is another phenol compound found in considerable amounts in green seaweed ethanolic extracts. This acid was found in Cladophora vagabunda ( $75.9 \mathrm{mg} / 100 \mathrm{~g}$ f.w.), in Ulva lactuca (72.8 mg/100 g f.w.) and the least in Enteromorpha intestinalis $(55.6 \mathrm{mg} / 100 \mathrm{~g}$ f.w.).

Table 4 outlines the following percentage order in which protocatechuic acid was found: $25 \%$ in Ulva lactuca, $21.27 \%$ in Cladophora vagabunda and $20.68 \%$ in Enteromorpha intestinalis from the total content of polyphenols identified in each alga.

\begin{tabular}{|l|l|l|c|}
\hline No. & \multicolumn{1}{|c|}{ Sample } & Taxonomy & $\begin{array}{c}\text { Concentration } \\
\text { (mg GAE } / 100 \mathrm{~g} \mathrm{f.w.)}\end{array}$ \\
\hline 1 & Ulva lactuca (L.) & Chlorophyta, Ulvales, Ulvaceae & $285.5 \pm 0.6$ \\
\hline 2 & $\begin{array}{l}\text { Enteromorpha intestinalis } \\
\text { (L.-Ness) }\end{array}$ & Chlorophyta, Ulvales, Ulvaceae & $268.8 \pm 0.7$ \\
\hline 3 & $\begin{array}{l}\text { Cladophora vagabunda } \\
\text { (L.-C Hoek) }\end{array}$ & $\begin{array}{l}\text { Chlorophyta, Cladophorales, } \\
\text { Cladophoraceae }\end{array}$ & $356.8 \pm 0.3$ \\
\hline
\end{tabular}

Table 2

TOTAL PHENOL CONTENT (TPC) OF ETHANOLIC EXTRACTS OF GREEN SEAWEEDS FROM THE ROMANIAN BLACK SEA COAST

\begin{tabular}{|c|l|c|c|c|}
\hline No. & \multicolumn{1}{|c|}{ Phenolic compound } & Ulva lactuca (L.) & $\begin{array}{l}\text { Enteromorpha } \\
\text { intestinalis } \\
\text { (L-Ness) } \\
\mathrm{mg} / 100 \mathrm{~g} \mathrm{fw} .\end{array}$ & $\begin{array}{l}\text { Cladophora } \\
\text { vagabunda } \\
\text { (L-C Hoek) } \\
\mathrm{mg} / 100 \mathrm{~g} \mathrm{f.w.}\end{array}$ \\
\hline 1 & Gallic acid & $5.3 \pm 0.1$ & $8.5 \pm 0.05$ & $7.9 \pm 0.1$ \\
\hline 2 & Protocatechuic acid & $72.8 \pm 0.2$ & $55.6 \pm 0.1$ & $75.9 \pm 0.03$ \\
\hline 3 & Gentisic acid & $130.5 \pm 0.1$ & $98.6 \pm 0.1$ & $155.3 \pm 0.15$ \\
\hline 4 & p-Hydroxybenzoic acid & $2.3 \pm 0.1$ & $1.5 \pm 0.05$ & $2.6 \pm 0.01$ \\
\hline 5 & Vanillic acid & $1.6 \pm 0.02$ & $1.8 \pm 0.02$ & $12.8 \pm 0.01$ \\
\hline 6 & Caffeic acid & $13.0 \pm 0.13$ & $15.7 \pm 0.11$ & $11.7 \pm 0.09$ \\
\hline 7 & Salicylic acid & $1.3 \pm 0.02$ & $0.9 \pm 0.01$ & 0 \\
\hline 8 & Benzoic acid & $1.5 \pm 0.03$ & 0 & 0 \\
\hline 9 & Ferulic acid & 0 & 0 & 0 \\
\hline 10 & Elagic acid & 0 & 0 & 0 \\
\hline 11 & p-Coumaric acid & 0 & 182.6 & 266.2 \\
\hline & Total & 228.3 & & 0 \\
\hline Values are mean \pm SD $(\mathrm{n}=3)$ & & 0 & \\
\hline
\end{tabular}

Table 3

INDIVIDUAL PHENOLIC CONCENTRATIONS DETERMINED BY HPLC -DAD IN GREEN SEAWEED FROM THE ROMANIAN BLACK SEA COAST 
Table 4

THE PERCENTAGES (\%) OF TOTAL PHENOLS AND PERCENTAGES (\%) OF MAJ OR PHENOL COMPOUND IDENTIFIED IN TESTED ALCOHOLIC BERRIES EXTRACTS DETERMINED BY HPLC-DAD REPORTED TO TPC VALUES

\begin{tabular}{|c|c|c|c|c|c|c|c|c|}
\hline \multirow{2}{*}{ No. } & \multirow{2}{*}{ Sample } & \multirow{2}{*}{$\begin{array}{l}\text { Total } \\
\text { phenols } \\
\text { identified } \\
\text { and } \\
\text { quantified } \\
\%\end{array}$} & \multicolumn{6}{|c|}{$\begin{array}{l}\text { The major phenolic compound } \\
\text { identified and quantified }\end{array}$} \\
\hline & & & $\begin{array}{l}\text { phenolic } \\
\text { compound }\end{array}$ & $\%$ & phenolic compound & $\%$ & $\begin{array}{l}\text { phenolic } \\
\text { compound }\end{array}$ & $\%$ \\
\hline 1 & Ulva lactuca & 79.96 & Gentisic acid & 46.0 & Protocatechuic acid & 25.5 & Caffeic acid & 4.55 \\
\hline 2 & $\begin{array}{l}\text { Enteromorpha } \\
\text { intestinalis }\end{array}$ & 67.93 & Gentisic acid & 36.68 & Protocatechuic acid & 20.68 & Caffeic acid & 5.84 \\
\hline 3 & $\begin{array}{l}\text { Cladophora } \\
\text { vagabunda }\end{array}$ & 74.60 & Gentisic acid & 43.52 & Protocatechuic acid & 21.27 & Caffeic acid & 3.28 \\
\hline
\end{tabular}

Another acid found in significantamounts is represented by caffeic acid: in Enteromorpha intestinalis $(15.7 \mathrm{mg} / 100$ $\mathrm{g}$ f.w. with a percentage of $5.84 \%)$, in Ulva lactuca (13.0 $\mathrm{mg} / 100 \mathrm{~g} \mathrm{f.w}$. with a percentage of $4.55 \%$ ) and in Cladophora vagabunda ( $11.7 \mathrm{mg} / 100 \mathrm{~g}$ f.w with a percentage of $3.28 \%$ ). Ithas been noted that in Cladophora vagabunda, the vanillic acid ( $12.8 \mathrm{mg} / 100 \mathrm{gf} . \mathrm{w})$ was found in comparable amounts with caffeic acid ( $11.7 \mathrm{mg} / 100 \mathrm{~g}$ f.w). The remainder phenolic acids which were identified and quantified through HPLC-DAD, were found in smaller concentrations. Due to different extraction methods and different species studied, as well as the measurements used and the lack of information regarding phenolic composition of Black Sea algae in literature on the matter, a direct comparison between our results and studies performed in other seas is not feasible.

\section{Antioxidant activity $(A C L)$}

It is very important to examine the correlation between the total phenol content and the total antioxidant activity $(A C L)$ in the studied algae. The extraction method used to obtain fluid extracts was cold macerated in 70\% concentration ethylic alcohol, for $24 \mathrm{~h}$ in the dark. A good total antioxidant capacity was generated, as it can be seen from the curves obtained using the Photochem instrument with ACL kitt (fig.4). Table 5 presents the results for ACL expressed as Trolox units equivalents ( $\mathrm{nmol} / \mathrm{g}$ of dry sample) for the three algae.
The highest $A C L$ values were registered by Cladophora vagabunda ( $64.15 \mathrm{nmol} / \mathrm{g}$ dry alga), followed by U/va lactuca $(22.8 \mathrm{nmol} / \mathrm{g}$ dry alga) and Enteromorpha intestinalis (10.4 nmol/g dry alga). This order is in accordance with the total polyphenol content (TPC) in the analyzed algae: Cladophora vagabunda $(325.8 \mathrm{mg} / 100 \mathrm{~g}$ f.w.), followed by Ulva lactuca ( $285.5 \mathrm{mg} / 100 \mathrm{~g}$ f.w.) and Enteromorpha intestinalis ( $268.8 \mathrm{mg} / 100 \mathrm{~g}$ f.w).

The results of this study confirm the fact that there is a strong correlation between total antioxidant activity $(\mathrm{ACL})$ and total polyphenol content (TCL).

It is believed that the antioxidant properties of polyphenols are the result of their ability to act as reducing agents, hydrogen donors and free radicals and of caffenol's function as metal chelator, which impede the catalytic functioning of metal in the radical initiation process [16, 46].

\section{Antibacterial activity}

The antibacterial activity of the three green algae is the result of their high phenolic compound concentrations. Figure 5 and figure 6 present the inhibition halos formed as a result of the own antimicrobial action exercised by each alga extract (Cladophora vagabunda, Ulva lactuca, Enteromorpha intestinales), on bacterial strains of Escherichia coli and Staphylococcus aureus.

It can be observed that the analyzed alga extracts exhibit differentradii for bacterial growth inhibition for each

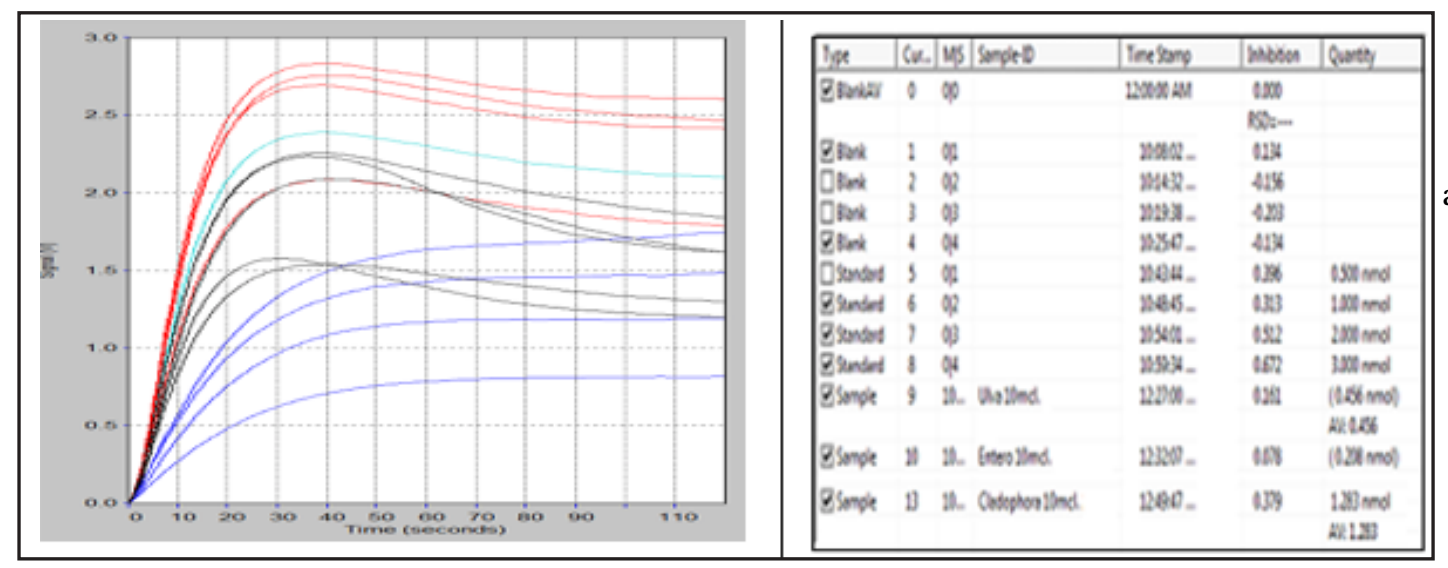

Fig. 4 Antioxidant activity (nmoles trolox / mg fresh weight) for undiluted sample and diluted samples 1:25 measured using PHOTOCHEM equipment

\begin{tabular}{|l|c|c|c|c|}
\hline $\begin{array}{c}\text { Sample } \\
\text { (type of green alga) }\end{array}$ & $\begin{array}{c}\text { Volume of } \\
\text { used sample } \\
(\mu \mathrm{L})\end{array}$ & $\begin{array}{c}\text { Analysis } \\
\text { time } \\
(\mathrm{sec} .)\end{array}$ & $\begin{array}{c}\text { Trolox units } \\
\text { equivalent } \\
\text { (nmol/sample } \\
\text { volume) }\end{array}$ & $\begin{array}{c}\text { Trolox units } \\
\text { equivalent } \\
\text { (nmol/g } \\
\text { dry sample) }\end{array}$ \\
\hline Ulva lactuca & 20 & 120 & 0.456 & 22.8 \\
\hline Enteromorpha intestinalis & 20 & 120 & 0.208 & 10.4 \\
\hline Cladophora vagabunda & 20 & 120 & 1.283 & 64.15 \\
\hline
\end{tabular}

Table 5 RESULTS OBTAINED FOR THE ACT DETERMINATION ON GREEN ALGAE EXTRACTS 


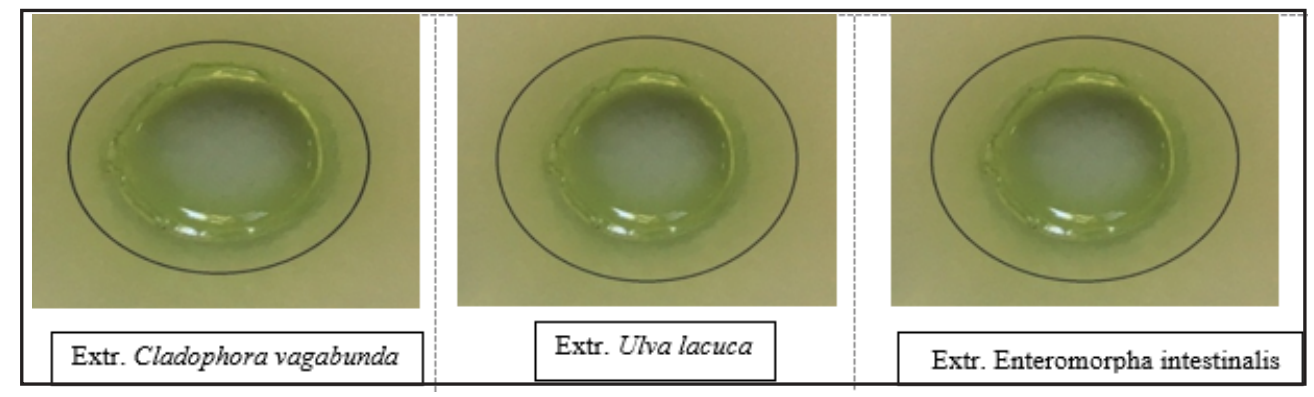

Fig.5 The antimicrobial effect of alcoholic alga extracts on Escherichia coli

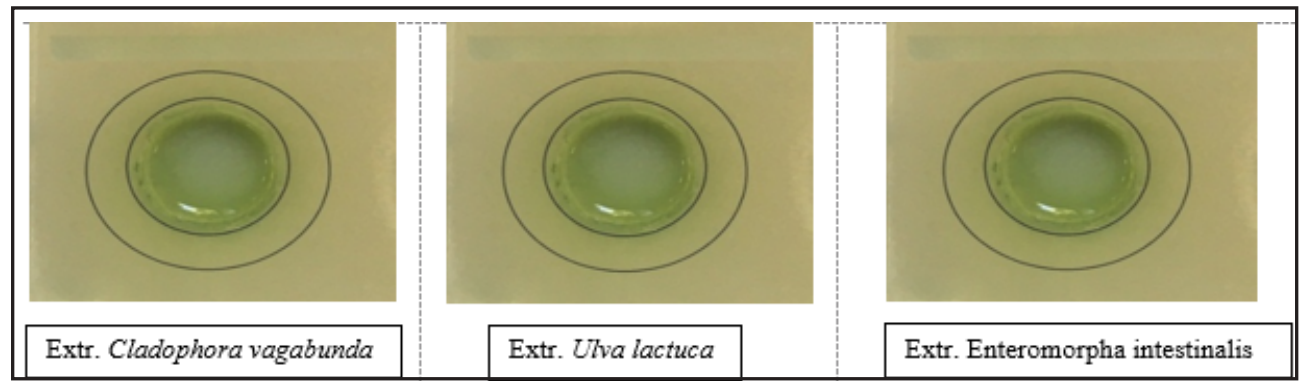

Fig.6 The antimicrobial effect of alcoholic alga extracts on Staphylococcus aureus

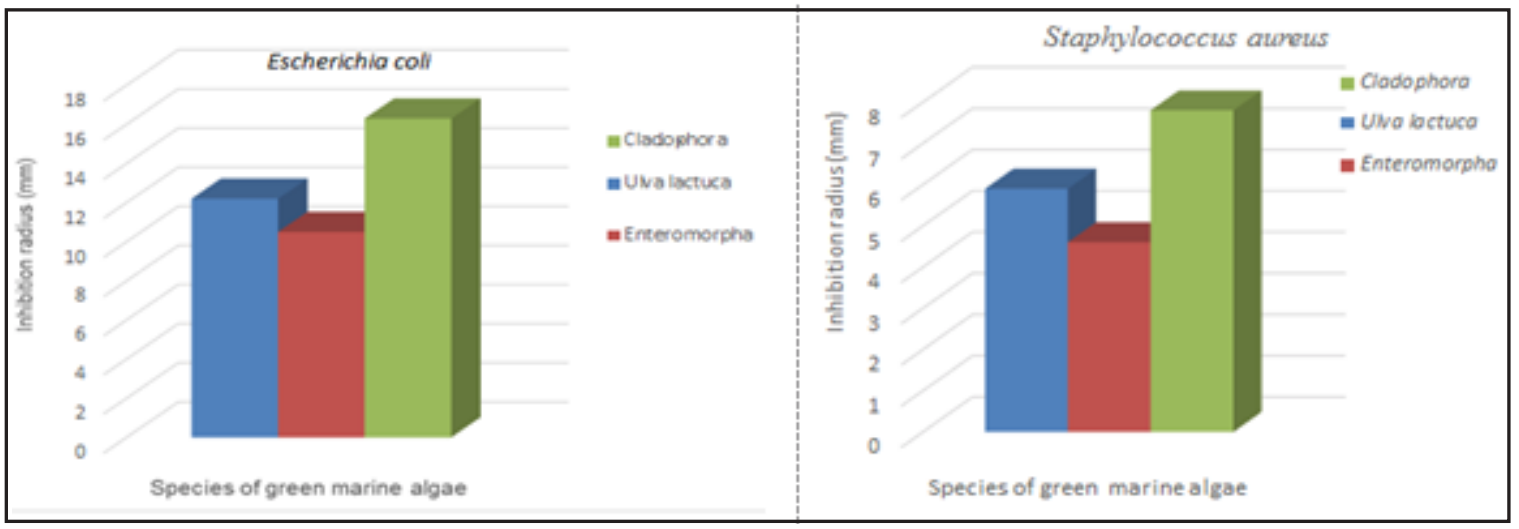

Fig.7. Antibacterial Activity of ethanolic extracts from green seaweeds in the Romanian Black Sea coast on strains of bacteria (Escherichia coli and Staphylococcus aureus)

of the three algae. This antimicrobial effect, evidenced through the size of the inhibition areas is an important property of seaweed, of great use in the pharmaceutical field. Figure 7 shows the graphical representation of antimicrobial activity of seaw eed extracts on the analyzed pathogen germs. Inhibition radii obtained for the studied algae extracts are similar in value, with a different antimicrobial effect on the bacterial strains that can be observed. In our study the highest activities of ethanol extracts ( $10.5 \mathrm{~mm}, 12.2 \mathrm{~mm}$ and $16.3 \mathrm{~mm}$ ) were recorded for Escherichia coli and the lowest $(4.6 \mathrm{~mm}, 5.9 \mathrm{~mm}$ and $7.8 \mathrm{~mm}$ ) for Staphylococcus aureus at $100 \mu \mathrm{g} / \mathrm{mL}$. Although literature on the matter holds few data regarding antibacterial activity of green alga in the Black Sea, our results are in accordance with the antibacterial activity of other green seaweed species (Ulva reticulate and Cladophora socialis) in ethanolic extracts that can be found in the Red Sea [47]. In literature, the maximum activity was recorded in ethanol and ethyl acetate extracts from seaweeds and both of these extracts exhibited reasonable activity against all the tested pathogens [48, 49], which confirms our choice of solvent. Studies performed on different types of seaweed originating from the territorial South African waters have been reported, in which the antibacterial activity manifests itself all throughout the year at different intensities [50].

Other researchers claim that the activity of algae originating from India's territorial waters can be due to the variation in cellular chemical and biological composition according to season, habitat, and life stage of the respective alga [51]. Recentstudies performed by Chinese researchers
[52] have shown that there is an evident seasonal variation in antibacterial activity of green algae harvested from China's territorial waters [52]. Also, Chinese researchers have observed that Ulva lactuca has the highest antibacterial activity from the beginning of winter (December) until mid-spring (April) [52].

\section{Conclusions}

This is the detailed study of in vitro antioxidant and antibacterial activity of seaweeds from the Romanian Black Sea coast in which phenolic compounds were identified and quantified from a range of green seaweeds. The results of this screening experiment demonstrated that extracts of the different seaweed species contain different levels of total and individual phenolics and possess diverse antioxidant and antibacterial properties.

Three green algae species from the Clorophyta class were analyzed: Ulva lactuca (L.), Enteromorpha intestinales (L-Nees) and Cladophora vagabunda (L-Hoek). The total phenolic content (TPC) as determined by spectrophotometry (the Folin-Ciocalteu method) was found in all studied algae, in varying concentrations. The highest total phenolic content was obtained for Cladophora vagabunda ( $325.8 \mathrm{mg} / 100 \mathrm{~g}$ f.w.), followed by U/va lactuca $(285.5 \mathrm{mg} /$ $100 \mathrm{~g}$ f.w.) and Enteromorpha intestinalis (268.8 mg/100g f.w.).

Using HPLC-DAD techniques 6 individual phenol compounds were found, in varying quantities, in all the analyzed algae. High contents were obtained for: gentisic acid (98.6-155.3 mg/100 g f.w.), protocatechuic acid 55.6$75.9 \mathrm{mg} / 100 \mathrm{~g}$ f.w.), caffeic acid (11.7-15.7 mg/100 g f.w.), 
gallic acid (5.3-8.5 mg/100 g f.w.), and in lower contents for $p$-vanillic acid (1.6-12.8 mg/100 g f.w.) and $p$ hydroxybenzoic acid (1.5-2.6 mg/100 g f.w.). Moreover, salicylic acid was found in Ulva lactuca ( $1.3 \mathrm{mg} / 100 \mathrm{~g}$ f.w.) and in Enteromorpha intestinalis ( $0.9 \mathrm{mg} / 100 \mathrm{~g} \mathrm{f.w.)}$, while benzoic acid was found in Ulva lactuca ( $1.5 \mathrm{mg} / 100$ $\mathrm{g}$ f.w.). The results of this study show that there is a strong correlation between the total antioxidant activity $(A C L)$, the antibacterial activity, and the total polyphenol content (TCL). Antioxidant activity, as determined through chemiluminescence, registers the same order as the total phenolic content: Cladophora vagabunda ( $64.15 \mathrm{nmol} / \mathrm{g}$ sample) followed by U/va lactuca ( $22.8 \mathrm{nmol} / \mathrm{g}$ sample) and Enteromorpha intestinalis (10.4 nmol/sample). The antibacterial activity for the two strains of bacteria analyzed in this study also registers the same order as that of the total phenolic content. What is more, ethanolic extracts from the green algae show larger areas of inhibition for Escherichia coli compared to Staphylococcus aureus. It must be noted that the Black Sea has an important potential of yielding pharmaceutically useful algae, which can be harnessed for the development of drugs for use in management of human pathogens, cancer, tumor, AIDS and many human degenerative diseases.

Acknowledgments. The authors would like to express appreciation for the financial support of the Romanian Ministry of Research UEFISCDI, for Complex Project no. 85 PCCDID 2018, Acronym INOBIOMAR, Projectcode PN-III-P1-1.2-PCCDI-2017-0701.

\section{References}

1.SDATMAN, E.R., Science 257, 1992, p. 1220.

2.BARCLAY, L.R.C, Can. J. Chem. 71, 1993, p.1.

3.ALKHAMAISEH, S. I., TAHER, M., AHMAD, F., SUSANTI, D., ICHWAN, S. J.A., Int. J. Phytomed. 3, 2011, p. 157.

4.GUPTA, S., ABU-GHANNAM, N., Innov. Food Sci. Emerg. Technol. 12, 2011, p. 600.

5.STANCIU, G., CHIRILA, E, DOBRINAS, S., NEGREANU-PIRJ OL, T., Rev. Chim. (Bucharest), 61, no. 1, 2010, p. 41.

6.STANCIU, G., CRISTACHE, N., LUPSOR, S., DOBRINAS, S., Rev. Chim.(Bucharest), 68, no. 7, 2017, p. 1429.

7.PALLAG, A., JURCA, T., SIRBU, V., HONIGES, A., JURCA, C., Rev. Chim. (Bucharest), 69, no. 2, 2018, p. 445.

8.YUAN, Y.V., WALSH, N.A., Food and Chemical Toxicology, 44, no.7, 2006, p. 1144.

9.ABD EL MEGEED, D.F., GHAREEB, D.A., ELSAYED, M., EL-SAADANI, M., Int. J. Agr. Polic. Res., 2, no.11, 2014. p. 373.

10.APPELTANS, W., AHYONG, S.T., ANDERSON, G., ANGEL, M.V., ARTOIS, T., BAILLY, N., BAMBER, R., BERTA, A., B£A-EWICZPASZKOWYCZ, M., BOCK, P., BOXSHALL, G., BOYKO, C.B., et al., Curr. Biol. 22, no. 23, 2012, p. 2189.

11.MARBÀ, N., KRAUSE-J ENSEN, D., OLESEN, B., CHRISTENSEN, P.B., MERZOUK, A., RODRIGUES, J., WEGEBERG, S., WILCE, R.T., Ambio, 46, Sup.1, 2017, p. 19.

12.COLLINS, K.G., GERALD, F., FITZGERALD, G.F., STANTON, C., ROSS,

R.P., Mar. Drugs, 14, no.3, 2016, p. 60.

13.TEICHBERG, M., FOX, M.T., OLSEN, Y.O., VALIELA, I., MARTINETTO, P., IRIBARNE, O., MUTO, E.Y., PETTI, M.A.V., CORBISIER, T.N., SOTOJIMÉNEZ, M., PÁEZ-OSUNA, F., CASTRO, P., FREITAS, H., ZITELLI, A., CARDINALETTI, M., TAGLIAPIETRA, D., Global Change Biol., 16, 2010, p. 2624.

14.YOSHIE, Y., WAND, W., HSIEH, Y.P., SUZUKI, T., J. Tokyo Univ. Fish, 88, 2002, p. 21.

15.CHAKRABORTY, K., LIPTON, A.P., PAULRAJ, R., CHAKRABORTY, R.D., Eur. J. Med. Chem., 45, 2010, p. 2237.

16.PANDIMA DEVI, K., SUGANTHY, N., KESIKA, P., KARUTHA PANDIAN, S., BMC Comp. Altern. Medicine, 8, 2008, p. 38.

17.VAIRAPPAN, C.S., SUZUKI, M., ISHII, T., OKINO, T., ABE, T., MASUDA, M., Phytochemistry, 69, 2008, p. 2490.

18.LAURIENZO, P., Ma. Drugs, 8, 2010, p. 2435.
19.ELNABRIS, K.J., ELMANAMA, A.A., CHIHADEH, W.N, J. Mar. Sci., 28, no.1, 2013, p. 81.

20.TASKIN, E., OZTURK, M., TASKIN, E., KURT, O., African J. Biotech., 6, 2007, p. 2746.

21.PRIYADHARSHINI, S., BRAGADEESWARAN, S., PRABHU, K., RAN, S.S., Asian Pacific J. Tropical Biomed, 1, 2011, p. 38.

22.WANG, R., PAUL, V.J., LUESCH, H., Biol. Med, 57, 2013, p. 14.

23.WANG, T., JONSDOTTIR, R., OLAFSDOTTIR, G., Food Chem .116, 2009, p. 240.

24.PATRA, J.K., RATH, S.K., JENA, K., RATHOD, V.K., THATOI, H.N., Turkish J. Biol, 32, 2008, p. 119.

25.PUSHPARAJ, A., RAUBBI, N.R.S., BALASANKAR, T., Int. J. Pharm. Tech Res., 6, no.1 2014, p. 1.

26.PINTEUS, S., SILVA, J., ALVES, C., HORTA, A., FINO, N., RODRIGUES, A.I., MENDES, S., PEDROSA, R., Food Chem., 218, 2017, p. 591.

27.ELSHOUNY, W., GAAFAR, R., ISMAIL, G., ELZANATY, M., Egypt. J. Exp. Biol. 13, 2017, p. 341.

28.BANSEMIR, A., BLUME, M., SCHRODER, S., LINDEQUIST, U., Aquaculture, 252, 2006, p. 79.

29.THANIGAIVEL, S., VIJAYAKUMAR, S., MUKHERJEE, A., CHANDRASEKARAN, N., THOMAS, J., Aquaculture, 433, 2014, p. 467. 30.WICHARD, T., CHARRIER, B., MINEUR, F., BOTHWELL, F.H., DE CLERCK, O., COATES, J. C., Frontiers in Plant Science, 6, 2015, p. 72. 31.ABDEL-FATTAH, A.F., EDREES, M., Phytochemistry, 12, 1973, p. 481.

32.ROBIC, A., BERTRAND, D., SASSI, J.F., LERAT, Y., LAHAYE, M., J. Appl. Phycol, 21, 2009, p. 451.

33.ALSUFYANI, T., ENGELEN, A. H., DIEKMANN, O.E., KUEGLER, S., WICHARD, T., Chem. Phys. Lipids, 183, 2014, p. 100.

34.HERNÁNDEZ-GARIBAY, E., ZERTUCHE-GONZÁLEZ, A., PACHECORUIZ, I., J. Appl. Phycol, 23, no.3, 2011, p. 537.

35.THANIGAIVEL, S., VIJAYAKUMAR, S., MUKHERJEE, A., CHANDRASEKARAN, N., THOMAS, I., Aquaculture, 433, 2014, p. 467. 36.TUNEY, I., CADIRCI, B.H, UNAL, D., SUKATAR, A., Turkish J. Biol., 30, 2006, p. 171.

37.SIRBU, R., ZAHARIA, T., NICOLAEV, S., BOLOGA, A., OCEANS- IEEE Conference Proceedings, Canada, 1-5, 2007, p. 137.

38.SIRBU, R., ZAHARIA, T., BECHIR, A., LILIOS, G., NICOLAEV, S., J. Environ. Prot. Ecol., 13, no. 1, 2012, p. 190.

39.CADAR, E., CHERIM, M., J. Sci.-Arts, 3, no. 44, 2017, p. 717.

40.HARDY, F.G., GUIRY, M.D., Atlas of the Seaweeds of Britain and Ireland. London, British Phycological Society, 2006.

41.GUIRY, M.D., Algae Base. World Register of Marine Species. Worldwide electronic publication, National University of Ireland, Galway, 2012.

42.FARVIN, S.K.H., JACOBSEN, C., Food Chemistry, 138, 2013, p. 1670. 43.SIDDIQUI, N., RAUF, A., LATIF, A., MAHMOOD, Z., J. Taibah Univ. Med. Sci., 12, no. 4, 2017. p. 360.

44.POPOV, I. N., LEWIN, G., Photosintesitized chemiluminiscence. Its medical and industrial applications for antioxidizability tests. In: A. M. Garcia-Campana, W.R.G. Baeyens (Eds.) Chemiluminiscence in Analytical Chemistry, Marcel Decker Inc., New York, 2001.

45.NEGREANU-PIRJ OL, T., NEGREANU-PIRJ OL, B., SIRBU, R., PARASCHIV, G., MEGHEA, A., J. Environ. Prot. Ecol., 13, no 3A, 2012, p. 1744.

46.MATANJU, P., MOHAMED, S., MUSTAPHA, N. M., MUHAMMAD, K., MING, C. M., J. Appl. Phycol., 20, 2008, p. 367.

47.SALEH, S., AL-SAIF, A.I., ABDEL-RAOUF, N., EL-WAZANANI, H.A., AREF, I.A., Saudi J. Biol. Sci., 21, 2014, p. 57.

48.OSMAN, M.E.H., ABOSHADY, A.M., ELSHOBARY, M.E., 2013, African J. Biotech, 12, no. 49, p. 6847 .

49.LI, Y., SUN, S., PU, X., YANG, Y., ZHU, F., ZHANG, S., XU, N., Sustainability, 10, 2018, p. 2158.

50.STIRK, W.A., REINECKE, D.L., STADEN, J.V., J. Appl. Phycol., 19, no.3, 2007, p. 271.

51.VALLINAYAGAM, K., ARUMUGAM, R., KANNAN, R., THIRUMARAN, G., ANANTHARAMAN, P., Global J. Pharmacol, 3, no.1, 2009, p. 50. 52.WAGIH, E.S. REDA, A., GAAFA, M., GEHAN, R., ISMAIL, A., ELZANATY, M.M., J. Exp. Biol., 13, no.1, 2017, p. 341.

Manuscript received: 26.07 .2018 